\title{
Research on the Concrete Mixture Stability and Sliding on the Inclined Plane
}

\section{Rokas Kudirka, Mindaugas Daukšys*, Svajūnas Juočiūnas}

Kaunas University of Technology, Faculty of Civil Engineering and Architecture

Studentu str. 48, LT-51367 Kaunas, Lithuania

*Corresponding author: mindaugas.dauksys@ktu.lt

$\Gamma$ crossef http://dx.doi.org/10.5755/j01.sace.26.1.21714

The stability of conventional concrete mixture was investigated using an inclined plane method. The experiment consisted of two steps: first, the research was conducted to obtain an effect of coarse aggregate content in aggregates mixture on the stability and sliding of concrete mixture, when the samples of fresh concrete are on the inclined plane without additional roughening of surface; second, the research was conducted to obtain an effect of inclined plane surface roughening on the stability and sliding of fresh concrete samples. During the research the condition was checked: the fresh concrete on the sloping plane will be stable, if the yield stress $\tau_{0}$ is higher than the shear stress $\tau_{\text {in. }}\left(\tau_{0} \geq \tau\right)$. The shear stresses and rheological property yield stresses of conventional concrete mixtures were calculated analytically by using an empirical formula. Test results showed that the increase of coarse aggregate (4/16 fraction gravel) content from about 417 to $1175 \mathrm{~kg}$ in concrete mixture is enough to achieve the stability of fresh concrete, when plane inclination angles are $25^{\circ}, 35^{\circ}$ and $45^{\circ}$, but not enough to stop sliding process. In this case, additional implements are needed to increase the adhesion of fresh concrete to the base. By using the inclined planes, which were coated with a special dimpled membrane and geotextile, the fresh concrete does not slide downwards by inclined plane. This article is based on master thesis topic "Investigations of Sloping Concrete Concreting Technologies".

Keywords: inclined plane method, concrete mixture, coarse aggregate, yield stress, sliding, roughening.

In modern buildings slope-type structures (arched, sloping and dome structures, reservoirs) are common, and different concrete technologies are applied for their installation. Performing concrete work of such structures it is necessary to properly solve the conditions of the concrete mix, i.e. to select such concrete technological parameters (Žiogas et al. 2012) so that the concrete mixture does not slides down and is well laid and packed.

One of the concrete mixture's rheological properties (in order to maintain the concrete mixture's stability at an angle of inclination of the inclined plane) is yield stress that must be not less than a certain size. Yield stress may be calculated by analysing the forces acting on the concrete mixture and the shear stresses it produces, depending on the angle of the plane inclination (Coussot and Boyer, 1995; Assaad and Khayat, 2004; Banfill, 2006; Khayat and Omran, 2009; Khayat et al. 2010). The relation between the flow factor of the concrete mixture and the yield stresses, when the components of the concrete mix change, were studied by the authors (Wallevik, 2003; Kamal et al. 2010).

\section{Introduction}

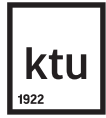

Journal of Sustainable Architecture and Civil Engineering Vol. 1 / No. 26 / 2020 pp. 87-97 DOI 10.5755/j01.sace.26.1.21714 
Fresh concrete mixture is a heterogeneous suspension which consists of various constituents. Those various constituents distinguish in different shape, size, material properties and has an effect on workability of fresh concrete (Jiao et al. 2017). Cement paste is one of the main constituent parts of concrete, which covers aggregates and fills gaps between them, and makes the flow of concrete mix easier. Koehler and Fowler (2004) confirmed that the increased volume of paste increases the flow factor and thus reduces yield stresses and plastic viscosity. Authors (Mork and Gjorv, 1997; Chen and Kwan, 2012; Dils et al. 2013) in their works concluded, that the yield stresses and plastic viscosity of cement paste depend on the mineral composition of the cement. It is estimated that in cement which contains high amount of $\mathrm{C}_{3} \mathrm{~A}$ and alkaline, the reduction of gypsum to silica ratio reduced the yield stresses, but did not change the plastic viscosity.

The aggregate type has an effect on the technology of concrete due to its bulk density and surface morphology. Crushed rock aggregates distinguish in angular shape and rough surface. This increase their surface area and reduce the amount of free water during mixture preparation. In addition, the angular shape is not favourable for particle flow and increases the resistance of friction between particles, thus significantly increasing the yield stresses and plastic viscosity, reducing the flow of the mixture (Westerholm et al. 2008; Aissoun et al. 2016). The main rheological properties of concrete mixture - yield stresses and plastic viscosity significantly depend on the type of aggregate, its chemical composition and content in the aggregate mixture, its packing density, fineness and surface texture (Jiao et al. 2017). In addition, that strongly depend on particle size distribution of mineral admixtures, its filling, morphology, dispersion and adsorption effects. In many studies (Ba and Zhang, 2003; Hu and Wang, 2011; Harini et al. 2012; Zhang et al. 2016) it was estimated that the yield stresses and plastic viscosity of the concrete mixture increase as the volume of a coarse aggregate increases, while increasing the amount of fine aggregate increases the yield stresses of the concrete mixture, but decreases the plastic viscosity. The addition of coarse aggregates increases the amount of mortar covering the surface of the aggregates, reduces the cohesive effect between the aggregates and the cement paste and reduces the friction between the aggregates. By increasing the volume of fine aggregates, the need for hard particle surface area and water increases, the friction between the coarse aggregates decreases, therefore the shear stresses are increased and the plastic viscosity is reduced. It was also concluded that the larger the size of maximum particles, the smaller the specific surface area and less mortar (cement paste) is required to cover the aggregates, and at the same time the smaller the values of rheological properties of the concrete mix, the less dilatation (increase of mixture viscosity while shear stresses increase) is expressed in mixture (Santos et al. 2015).

The aim of this study is to determine an effect of coarse aggregate content in the total aggregates mixture on the stability and sliding of fresh concrete, when the samples of fresh concrete are on the inclined plane without and with additional roughening of surface.

\begin{tabular}{|c|c|c|}
\hline \multirow{4}{*}{$\begin{array}{r}\text { Materials } \\
\text { and testing } \\
\text { methods }\end{array}$} & & \\
\hline & Fineness by Blaine air-permeability apparatus, $\mathrm{m}^{2} / \mathrm{kg}$ & 410 \\
\hline & Specific gravity, $\mathrm{kg} / \mathrm{m}^{3}$ & 3050 \\
\hline & Dry bulk density, $\mathrm{kg} / \mathrm{m}^{3}$ & 1230 \\
\hline \multirow{4}{*}{$\begin{array}{l}\text { Table } 1 \\
\text { Physical and mechanical } \\
\text { properties of Portland } \\
\text { cement CEM I 42.5 R }\end{array}$} & Normal consistency by Vicat apparatus, \% & 26,5 \\
\hline & Volume expansion, $\mathrm{mm}$ & 0.8 \\
\hline & Initial time of setting by Vicat apparatus, min & 195 \\
\hline & $2 / 28$ days compressive strength, $\mathrm{MPa}$ & $27.1 / 54.0$ \\
\hline
\end{tabular}

Portland cement type CEM I 42.5 R from JSC "Akmenès cementas" (Lithuania) was used. The physical and mechanical properties of Portland cement are presented in Table 1

The fine aggregate washed sand sourced from "Kvesu quarry" (Lithuania) with the fractions of $0 / 1$ and $0 / 4$ was used. Following character- 
istics were determined: bulk densities of $1521 \mathrm{~kg} / \mathrm{m}^{3}$ and $1711 \mathrm{~kg} / \mathrm{m}^{3}$, particles densities of $2655 \mathrm{~kg} / \mathrm{m}^{3}$ and fineness modules of 1.78 and 2.62. The coarse aggregate gravel with the fraction of 4/16 was used. Following characteristics were determined: bulk density of $1657 \mathrm{~kg} / \mathrm{m}^{3}$ and particle density of $2665 \mathrm{~kg} / \mathrm{m}^{3}$. Characteristics of the aggregates in accordance to the standard LST EN 12620 are presented in Table 2.

The plasticizing admixture Glenium SKY 628 supplied by BASF (Italy), based on polycarboxylate resin was used for the research. Technical data: the

\begin{tabular}{c|c|c|c}
\hline \multirow{2}{*}{$\begin{array}{c}\text { Size of the sieve } \\
\text { mesh, mm }\end{array}$} & \multicolumn{3}{|c}{ The partial residue, \% } \\
\cline { 2 - 4 } & $\begin{array}{c}\text { Sand frac- } \\
\text { tion } 0 / 1\end{array}$ & $\begin{array}{c}\text { Sand fraction } \\
0 / 4\end{array}$ & $\begin{array}{c}\text { Gravel fraction } \\
4 / 16\end{array}$ \\
\hline 32.0 & - & - & 100.0 \\
\hline 16.0 & - & - & 93.0 \\
\hline 8.0 & 100.0 & 100.0 & 25.4 \\
\hline 4.0 & 100.0 & 97.5 & 0.4 \\
\hline 2.0 & 99.9 & 87.7 & 0 \\
\hline 1.0 & 98.1 & 71.9 & 0 \\
\hline 0.500 & 92.5 & 56.0 & 0 \\
\hline 0.250 & 28.0 & 17.4 & 0 \\
\hline 0.125 & 3.2 & 4.6 & 0 \\
\hline 0 & 0 & 0 & 0 \\
\hline
\end{tabular}

Table 2

Fine and coarse aggregates granulometric composition

density of water solution $1.06 \mathrm{~kg} / \mathrm{l}$; brown liquid; chloride quantity $<0.1 \%$; alkali quantity $<2.5 \%$. It was added in amount of $1.0 \%$ by weight of cement. The form release agent Rheofinish 215 supplied by BASF (Korea) was used. Technical data: the density of water solution $0.96 \mathrm{~kg} / \mathrm{l}$; white liquid; viscosity $30 \mathrm{MPa} \cdot \mathrm{s}$; $\mathrm{pH}$ value -8.5 ; temperature of using from $0^{\circ} \mathrm{C}$ to $+20 \pm 5^{\circ} \mathrm{C}$. Formwork surface (plywood) was covered within the excessive amount of form release agent and then was cleaned by the soft cloth according to producer recommendation.

The concrete mixtures were prepared according to the requirements of standard LST EN 206 using dry materials. In the laboratory, the concrete mixtures were mixed using forced type concrete mixer ZYKLOS Rotating Pan Mixer. The process of preparation of concrete mixture was divided into two stages. At the first stage, cement, fine and coarse aggregates and $2 / 3$ of water were mixed for about 2 minutes. At the second stage, the remaining amount of water was added with plasticizing admixture and mixed for about 1 minute. During the mixing process, cement, fine and coarse aggregates were dosed by weight while water and plasticizing admixture were dosed by volume.

The consistency of fresh concrete was determined in accordance to the standard LST EN 12350-2, the density of fresh concrete in accordance to the standard LST EN 12350-5:2009 and the air content of the compacted fresh concrete in accordance to LST EN 12350-7.

The inclined phenolic formwork plywood planes were coated with a special dimpled membrane Guttabeta Drain (Gutta Switzerland) and geotextile DuPont ${ }^{\mathrm{TM}}$ Geoproma $^{\circledR}$ (DuPont de Nemours Luxembourg S.à r.l). Membrane (Fig. 1a) is made from high-density polyethylene (HDPE), stud height approx. $8 \mathrm{~mm}$, studs per 1860 piece $/ \mathrm{m}^{2}$, air volume between studs approx. $5.3 \mathrm{l} / \mathrm{m}^{2}$. Geotextile (Fig. 1b) is made from a $100 \%$ thermally bonded polypropylene, unit weight $90 \mathrm{~g} / \mathrm{m}^{2}$, tensile strength $5.0 \mathrm{kN} / \mathrm{m}$, elongation (max. strength) $40 \%$, opening size $175 \mu \mathrm{m}$. Uniformity of surface roughness of used materials for plywood planes coating was not obtained.

For the inclined plane (IP) method a truncated cone of $100 \mathrm{~mm}$ in height, of $100 \mathrm{~mm}$ in diameter at the top and of $200 \mathrm{~mm}$ in diameter at the bottom was used. At the beginning, the truncated cone was placed on the top of inclined plane, filled with fresh concrete and it compacted by rod 10 times. After the cone was removed immediately in one move, the time of concrete mixture sample sliding downward was measured. If some part of the sample slides down along an inclined plane, this 
Fig. 1

For plywood plane surface roughening used materials: membrane (a) and geotextile (b)

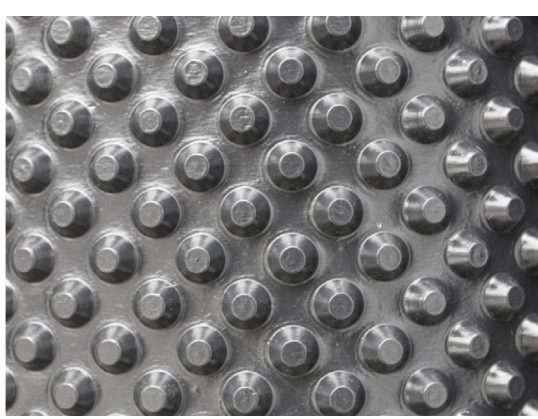

(a)

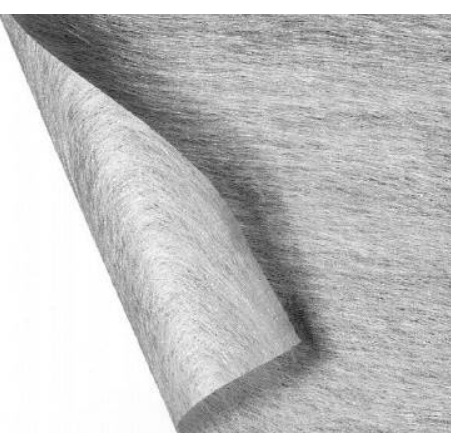

(b)

concrete mixture isn't stable. According to literature review were chosen three angle of the plane inclination: $25^{\circ}, 35^{\circ}$ and $45^{\circ}$. View of the inclined planes are given in Figs 4 and 5 .

The shear stresses $\mathrm{t}$ in the concrete mixture results from the tangential component of the force of gravity (Khayat and Omran, 2009). Shear stress can be calculated according to equation (1):

$\tau=\rho_{m} \cdot g \cdot h \cdot \sin \alpha$

here: $\rho_{m}$ - the density of fresh concrete, $\mathrm{g} / \mathrm{cm}^{3} ; g$ - the constant of gravitation $\left(9.81 \mathrm{~m} / \mathrm{s}^{2}\right) ; h$ - the characteristic height of spread concrete sample, $\mathrm{cm} ; \alpha$ - the angle of the plane inclination, ${ }^{\circ}$.

From Eq. 1 we can see that the shear stresses in a fresh concrete depends on the characteristic height $h$ of spread sample and the angle a of the plane inclination. The concrete mixture will be stable on a sloping plane if its yield stress $\tau_{0}$ is greater than the shear stress $\tau$, which appears in the fresh concrete:

$\tau_{0} \geq \tau$

The yield stress values for all concrete mixture composition were calculated in accordance with equation (3). For calculation was used an empirical formula proposed by Skripkiūnas (1993):

$$
\tau_{0}=\frac{0.00815 \cdot \rho_{m}}{\left(\sqrt{\frac{0.498}{30-S L}-0.001724}-0.024\right)^{2}}
$$

here: $\tau_{0}$ - the yield stress of fresh concrete, $\mathrm{Pa} ; \rho_{m}$ - the density of fresh concrete, $\mathrm{kg} / \mathrm{m}^{3} ; \mathrm{SL}$ - the slump value of fresh concrete, $\mathrm{cm}$.

Sliding speed of concrete mixture specimen moving down plane with different angle of the plane inclination can be calculated according to equation (4):

$$
V=s / t
$$

here: $V$ - sliding speed of concrete mixture specimen moving down plane, $\mathrm{cm} / \mathrm{s} ; d$ - total distance of travel, $\mathrm{cm} ; t$ - total time, when the specimen reach the bottom, $\mathrm{s}$.

One of the aims of the research was to investigate an effect of coarse aggregate - gravel of fraction $4 / 16 \mathrm{~mm}$ quantity on the technological and rheological properties of fresh concrete with increasing the quantity of coarse aggregate and decreasing the total quantity of sand (fraction $0 / 1 \mathrm{~mm}$ and 
fraction $0 / 4 \mathrm{~mm}$ ) in the total aggregates mixture. The content of gravel of fraction $4 / 16 \mathrm{~mm}$ was changed from 22 to $62 \%$ according to mass in respect to total aggregates mixture content. The mixture compositions for all concretes (BT1-0 - BAT-6) used in this research are presented in Table 3.

\begin{tabular}{|c|c|c|c|c|c|c|c|c|}
\hline \multirow[t]{2}{*}{ Materials } & \multirow{2}{*}{$\stackrel{\vec{z}}{5}$} & \multicolumn{7}{|c|}{$\begin{array}{l}\text { The mark of concrete mixture proportion. } \\
\text { The amount of materials per cu. m. of concrete mixture, } \mathrm{kg}\end{array}$} \\
\hline & & BT1-0 & BT1-1 & BT1-2 & BT1-3 & BT1-4 & BT1-5 & BT1-6 \\
\hline CEM I 42.5 R & $\mathrm{kg}$ & 330 & 330 & 330 & 330 & 330 & 330 & 330 \\
\hline Water & l & 178 & 178 & 178 & 178 & 178 & 178 & 178 \\
\hline Water to cement ratio & - & 0.54 & 0.54 & 0.54 & 0.54 & 0.54 & 0.54 & 0.54 \\
\hline $\begin{array}{l}\text { Coarse aggregate ratio to } \\
\text { total aggregate mixture }\end{array}$ & - & 0.22 & 0.32 & 0.37 & 0.42 & 0.47 & 0.52 & 0.62 \\
\hline Sand of fraction $0 / 1 \mathrm{~mm}$ & $\mathrm{~kg}$ & 492 & 429 & 397 & 366 & 334 & 303 & 240 \\
\hline Sand of fraction $0 / 4 \mathrm{~mm}$ & $\mathrm{~kg}$ & 986 & 860 & 797 & 733 & 671 & 607 & 480 \\
\hline Gravel of fraction $4 / 16 \mathrm{~mm}$ & $\mathrm{~kg}$ & 417 & 607 & 702 & 796 & 891 & 986 & 1175 \\
\hline Superplasticizer & $\mathrm{kg} / \mathrm{l}$ & 3.74 & 3.74 & 3.74 & 3.74 & 3.74 & 3.74 & 3.74 \\
\hline
\end{tabular}

The influence of gravel content in the total aggregates mixture on the entrapped air content in fresh concrete (a) and the density of fresh concrete (b) is presented in Figs 2. From Fig. 2a we can see that by increasing the content of gravel (fraction 4/16) in the total aggregates mixture from 22 to $62 \%$, the entrapped air content in fresh concrete decreases from 7.9 to $1.4 \%$. The entrapped air content in fresh concrete is lowest when the gravel (fraction 4/16) content in the total aggregates mixture is about $62 \%$ (the fine aggregate content is decrease to $38 \%$, respectively). The function graph (Fig. 2b) shows that when the content of gravel (fraction 4/16) in the total aggregates mixture increases from 22 to $62 \%$, the density of fresh concrete increases from 2160 to $2420 \mathrm{~kg} / \mathrm{m}^{3}$. When particles have a larger distribution density and a smaller surface area, the entrapped air content in fresh concrete is lower, while the density of fresh concrete is higher.

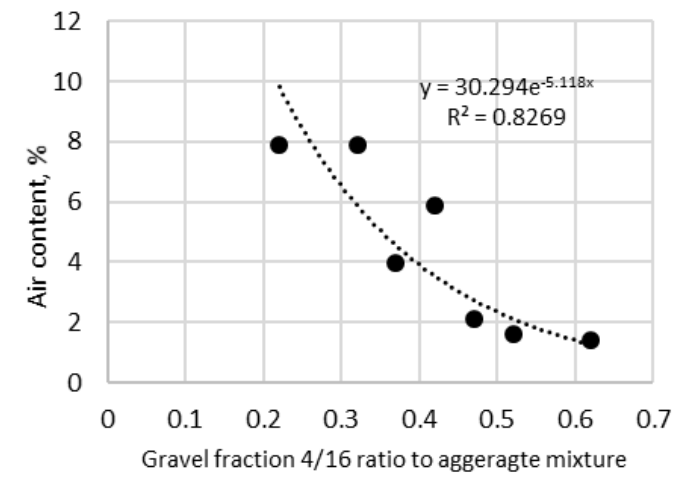

(a)

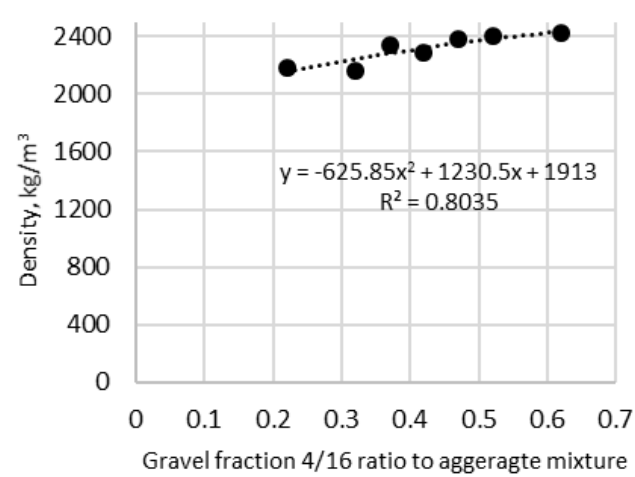

(b)
Fig. 2

The influence of gravel content in the total aggregates mixture on the entrapped air content in fresh concrete (a) and the density of fresh concrete (b)

The influence of gravel content in the total aggregates mixture on the consistency (a) and yield stress (b) of fresh concrete is presented in Figs 3. 
Fig. 3

The influence of gravel content in the total aggregates mixture on the consistency (a) and yield stress $(b)$ of fresh concrete

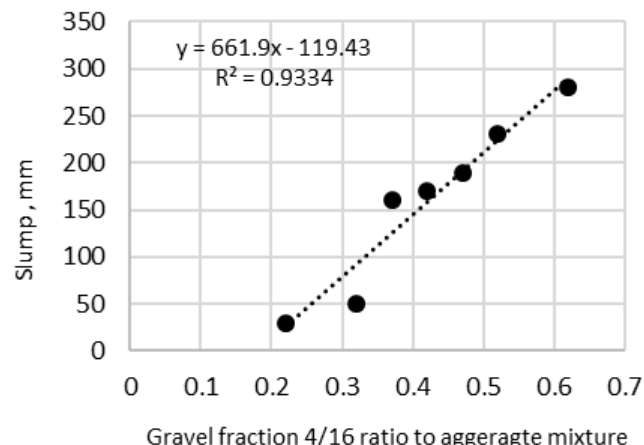

(a)

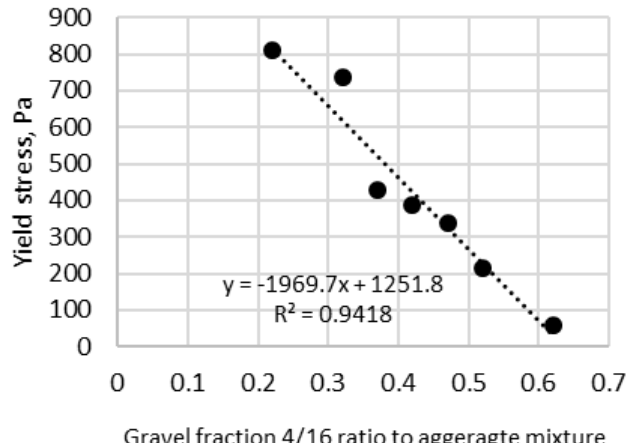

(b)

The function graphs reveal that gravel (fraction 4/16) content in the total aggregates mixture affects the slump and yield stress values of fresh concrete. By increasing the content of gravel (fraction 4/16) in the total aggregates mixture from 22 to $62 \%$ (the fine aggregate content decreases from 78 to $38 \%$, respectively), the slump values of fresh concrete increase from 30 to $280 \mathrm{~mm}$ and yield stresses values of the concrete decrease from 809.98 to $60.21 \mathrm{~Pa}$.

Calculated results of the sliding speed $(V)$ and shear stress $(\tau)$ of fresh concrete with different angle of the plane inclination, when the gravel (fraction 4/16) content in the total aggregates mixture varied in the range from 22 to $62 \%$, are given in Table 4 .

Table 4

The results of the sliding speed and shear stress of concrete mixtures

with different angle of the plane inclination, when the gravel content in the total aggregates mixture increases from 22 to $62 \%$

\begin{tabular}{|c|c|c|c|c|c|c|}
\hline \multirow{2}{*}{$\begin{array}{l}\text { The mark } \\
\text { of concrete } \\
\text { mixture } \\
\text { proportion }\end{array}$} & \multirow{2}{*}{$\begin{array}{l}\text { Sliding speed } \\
(V) \text { and shear } \\
\text { stress }(\tau)\end{array}$} & \multicolumn{3}{|c|}{ Angle of inclination, ${ }^{\circ}$} & \multirow{2}{*}{ Equation } & \multirow{2}{*}{ 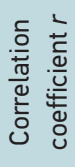 } \\
\hline & & 25 & 35 & 45 & & \\
\hline \multirow{2}{*}{ BT1-0 } & $V, \mathrm{~cm} / \mathrm{s}$ & 25.90 & 51.80 & 98.30 & $y=0.1027 x^{2}-3.5737 x+51.036$ & 1.00 \\
\hline & $\tau, P a$ & 183.98 & 412.07 & 636.90 & $y=-0.0162 x^{2}+23.784 x-400.46$ & 1.00 \\
\hline \multirow{2}{*}{ BT1-1 } & $V, \mathrm{~cm} / \mathrm{s}$ & 22.80 & 51.80 & 142.50 & $y=0.3083 x^{2}-15.597 x+220.03$ & 1.00 \\
\hline & $\tau, P a$ & 154.25 & 471.80 & 811.36 & $y=0.1101 x^{2}+25.15 x-543.31$ & 1.00 \\
\hline \multirow{2}{*}{ BT1-2 } & $V, \mathrm{~cm} / \mathrm{s}$ & 14.30 & 42.50 & 81.40 & $y=0.053 x^{2}-0.3525 x-10.076$ & 1.00 \\
\hline & $\tau, P a$ & 110.01 & 461.72 & 1051.35 & $y=1.1896 x^{2}-36.208 x+271.69$ & 1.00 \\
\hline \multirow{2}{*}{ BT1-3 } & $V, \mathrm{~cm} / \mathrm{s}$ & 17.50 & 47.50 & 158.30 & $y=0.4044 x^{2}-21.265 x+296.45$ & 1.00 \\
\hline & $\tau, P a$ & 21.81 & 60.49 & 60.10 & $y=-0.1953 x^{2}+15.585 x-245.76$ & 1.00 \\
\hline \multirow{2}{*}{ BT1-4 } & $V, \mathrm{~cm} / \mathrm{s}$ & 33.50 & 95.00 & 158.30 & $y=0.0093 x^{2}+5.5882 x-112$ & 1.00 \\
\hline & $\tau, P a$ & 15.71 & 50.83 & 101.00 & $y=0.0753 x^{2}-1.007 x-6.1822$ & 1.00 \\
\hline \multirow{2}{*}{ BT1-5 } & $V, \mathrm{~cm} / \mathrm{s}$ & 12.10 & 32.20 & 63.30 & $y=0.0553 x^{2}-1.3087 x+10.301$ & 1.00 \\
\hline & $\tau, P a$ & 97.22 & 393.16 & 761.78 & $y=0.3634 x^{2}+7.792 x-324.68$ & 1.00 \\
\hline \multirow{2}{*}{ BT1-6 } & $V, \mathrm{~cm} / \mathrm{s}$ & 12.10 & 28.50 & 63.30 & $y=0.0923 x^{2}-3.9011 x+51.964$ & 1.00 \\
\hline & $\tau, P a$ & 24.72 & 149.96 & 198.67 & $y=-0.3826 x^{2}+35.481 x-623.17$ & 1.00 \\
\hline
\end{tabular}


Results given in Table 4 reveals that the angle of the plane inclination affects the sliding speed and shear stress of the fresh concrete samples. By increasing the angle of the plane inclination from 25 to $45^{\circ}$, the sliding speed of fresh concrete sample increase. When the angle of the plane inclination was $45^{\circ}$, was obtained the highest speed $158.3 \mathrm{~cm} / \mathrm{s}$ (compositions BT1-3 and BT1-4). The lowest speed $12.1 \mathrm{~cm} / \mathrm{s}$ (compositions BT1-5 and BT1-6) was obtained when the angle of the plane inclination was $25^{\circ}$. When the angle of the plane inclination increases from 25 to $45^{\circ}$, the shear stress of concrete mixture varied in the range from 183.98 to $15.71 \mathrm{~Pa}$ (when $\alpha=25^{\circ}$ ), from 412.07 to $50.83 \mathrm{~Pa}\left(\right.$ when $\alpha=35^{\circ}$ ) and from 636.90 to $101.00 \mathrm{~Pa}$ (when $\alpha=45^{\circ}$ ). By using Microsoft Excel program was identified the best dependence between the sliding speed and shear stress values of fresh concrete samples according to the best empirical coefficients values of equations. The empirical coefficient of equation was used to calculate the correlation coefficient or Pearson coefficient. It is known that Pearson coefficient is evaluating the strength of linear relationship between variables and it should be closer to 1. By determining correlation coefficient, it was decided which equation describes the best distribution of statistical data.

\begin{tabular}{c|c|c|c|c|c|c|c|}
\hline \multirow{2}{*}{$\begin{array}{c}\text { The mark } \\
\text { of concrete } \\
\text { mixture } \\
\text { proportion }\end{array}$} & \multirow{2}{*}{$\tau_{0}, \mathrm{~Pa}$} & \multicolumn{3}{|c|}{ Angle of inclination, } & \multicolumn{3}{c}{ Checking if condition $\mathrm{\tau}_{0} \geq \mathrm{\tau}$} \\
\cline { 3 - 8 } & & 25 & 35 & 45 & 25 & 35 & 45 \\
\hline BT1-0 & 809.98 & 183.98 & 412.07 & 636.90 & Stable & Stable & Stable \\
\hline BT1-1 & 736.84 & 154.25 & 471.80 & 811.36 & Stable & Stable & Not stable \\
\hline BT1-2 & 427.23 & 97.22 & 393.16 & 761.78 & Stable & Stable & Not stable \\
\hline BT1-3 & 386.68 & 110.01 & 461.72 & 105.35 & Stable & Not stable & Stable \\
\hline BT1-4 & 337.35 & 24,72 & 149.96 & 198.67 & Stable & Stable & Stable \\
\hline BT1-5 & 213.09 & 21.81 & 60.49 & 60.10 & Stable & Stable & Stable \\
\hline BT1-6 & 60.21 & 15.71 & 50.83 & 101.00 & Stable & Stable & Not stable \\
\hline
\end{tabular}

From results given in Table 5 we can see that the fresh concrete sample is stable on a sloping plane if its yield stress $\tau_{0}$ is greater than the shear stress $\tau$, which appears in the fresh concrete.

View of the inclined plane (IP) test method is shown in Figs 4 (a-c). The samples of fresh concrete are stable, but slides down along an inclined plane, which made form plywood and for roughen-

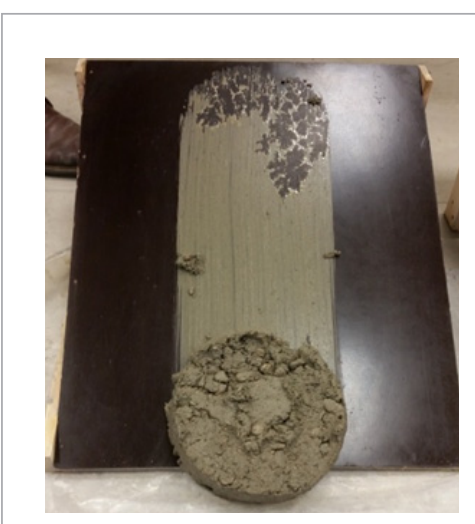

(a)

$\alpha=25^{\circ}$

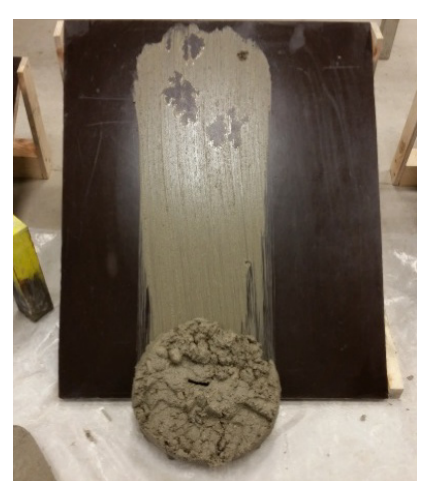

(b)

$\alpha=35^{\circ}$

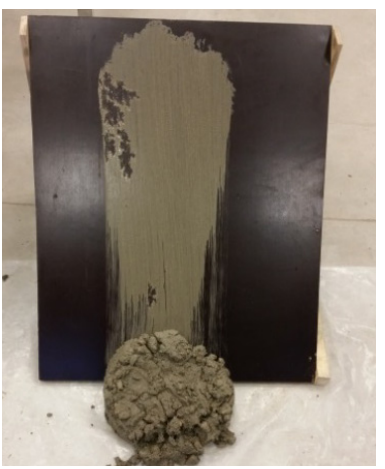

(c)

$\alpha=45^{\circ}$

\section{Table 5}

Checking if yield stress $\tau_{0}$ is greater than the shear stress $\tau$ condition
Fig. 4

View of the inclined plane method test 
ing of surface was not used any material. Test results (Table 5) show that the increase of gravel (fraction 4/16) content from about 417 to $1175 \mathrm{~kg}$ in concrete mixture is not enough to achieve the stability of fresh concrete sample, when plane inclination angles are $25^{\circ}, 35^{\circ}$ and $45^{\circ}$. Also is not enough to stop sliding process. In this case, additional implements are needed to increase the adhesion of fresh concrete to the base. It was decided to increase the adhesion of fresh concrete to the base by using special dimpled membrane (Fig. 1a) and geotextile (Fig. 1b).

For the next step of experiment were chosen two concrete mixture composition: BT1-3 and BT1-5. The yield stresses and technological properties of those mixtures are presented in Table 6.

\section{Table 6 \\ Comparison of the yield stress and technological properties of concrete mixtures}

\begin{tabular}{c|c|c|c|c|c}
\hline $\begin{array}{c}\text { The mark of } \\
\text { concrete mixture } \\
\text { proportion }\end{array}$ & $\begin{array}{c}\text { Coarse aggregate } \\
\text { ratio to total } \\
\text { aggregate mixture }\end{array}$ & $\begin{array}{c}\text { Air con- } \\
\text { tent, } \%\end{array}$ & Density, $\mathrm{kg} / \mathrm{m}^{3}$ & $\begin{array}{c}\text { Slump value, } \\
\mathrm{mm}\end{array}$ & $\mathrm{\tau}_{0}, \mathrm{~Pa}$ \\
\hline BT1-3 & 0.42 & 5.2 & 2279 & 160 & 416.09 \\
\hline BT1-5 & 0.52 & 4.1 & 2341 & 230 & 207.85 \\
\hline
\end{tabular}

Calculated results of the sliding speed $(V)$ and shear stress $(\tau)$ of fresh concrete samples, when angle of the plane inclination varied from 25 to $45^{\circ}$ and for roughening of plywood surface were used membrane and geotextile, are presented in Table 7.

\section{Table 7}

The results of the sliding speed and shear stress of fresh concrete samples with different angle of the plane inclination, when for roughening of plywood surface were used membrane and geotextile

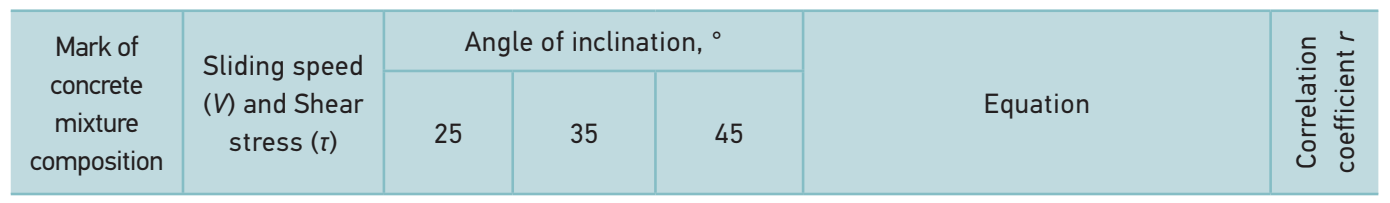

For roughening of plywood surface was used membrane

\begin{tabular}{l|c|c|c|c|c|c}
\hline \multirow{2}{*}{ BT1-3 } & $V, \mathrm{~cm} / \mathrm{s}$ & 0 & 0 & 0 & - & - \\
\cline { 2 - 7 } & $\tau, P a$ & 281.10 & 526.51 & 760.95 & $\mathrm{y}=-5.4835 \mathrm{x}^{2}+261.85 \mathrm{x}+24.732$ & 1.00 \\
\hline \multirow{2}{*}{ BT1-5 } & $V, \mathrm{~cm} / \mathrm{s}$ & 0 & 0 & 31.70 & $\mathrm{y}=15.833 \mathrm{x}-21.111$ & 1.00 \\
\cline { 2 - 7 } & $\tau, P a$ & 212.76 & 639.16 & 977.06 & $\mathrm{y}=-44.253 \mathrm{x}^{2}+559.16 \mathrm{x}-302.14$ & 0.86 \\
\hline
\end{tabular}

For roughening of plywood surface was used geotextile

\begin{tabular}{l|c|c|c|c|l|c}
\hline \multirow{2}{*}{ BT1-3 } & $V, \mathrm{~cm} / \mathrm{s}$ & 0 & 56.40 & 93.40 & $\mathrm{y}=-9.7143 \mathrm{x}^{2}+85.579 x-75.864$ & 1.00 \\
\cline { 2 - 7 } & $\tau, P a$ & 251.51 & 765.83 & 1008.25 & $\mathrm{y}=-135.95 \mathrm{x}^{2}+922.16 \mathrm{x}-534.7$ & 1.00 \\
\hline \multirow{2}{*}{ BT1-5 } & $V, \mathrm{~cm} / \mathrm{s}$ & 0 & 9.30 & 50.90 & $\mathrm{y}=16.102 \mathrm{x}^{2}-38.962 x+22.86$ & 1.00 \\
\cline { 2 - 7 } & $\tau, P a$ & 212.76 & 245.83 & 586.24 & $\mathrm{y}=153.67 \mathrm{x}^{2}-427.93 \mathrm{x}+487.03$ & 1.00 \\
\hline
\end{tabular}

When the angle of the plane, which is covered using membrane and geotextile, inclination increases from 25 to $45^{\circ}$, the shear stress of concrete mixture increase. The sliding speed in some cases didn't increase and was equal 0 , i.e. sliding process of fresh concrete samples on a sloping plane was stopped (Table 7). Roughening of plywood surface by using membrane and geotextile affects the sliding process of fresh concrete samples. Due to dimpled membrane studs, which are approx. $8 \mathrm{~mm}$ height, effect on sliding process is bigger compering to geotextile effect on sliding process.

Views of the inclined plane (IP) test method, when for roughening of plywood surface were used membrane and geotextile, are presented in Figs 6 (a-c) and Figs 7 (a-c). 

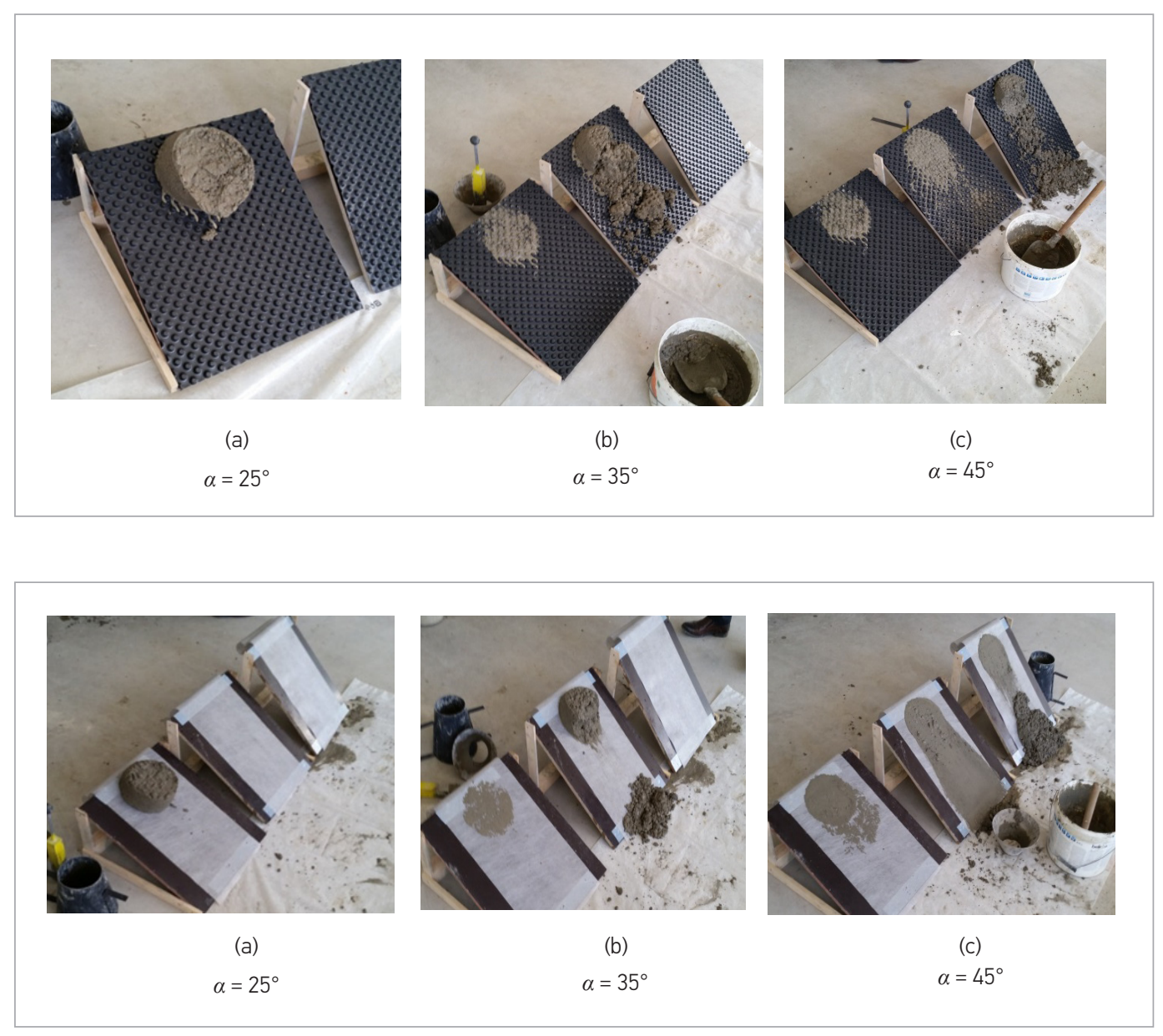

From Figs $6 a$ and $7 \mathrm{a}$ we can see that fresh concrete samples are stable on a sloping plane (when $\alpha=$ $25^{\circ}$ ) and also didn't slides down along an inclined plane. Figs $6 \mathrm{~b}$ and $7 \mathrm{~b}$ show that some part of fresh concrete samples isn't stable on a sloping plane (when $\alpha=35^{\circ}$ ) and only unstable part of fresh concrete sample slides down along an inclined plane. Figs $6 c$ and $7 c$ show that fresh concrete samples aren't stable on a sloping plane (when $\alpha=35^{\circ}$ ) and slides down along an inclined plane.

From results given in Table 8 we can see that the fresh concrete sample is stable on a sloping plane if its yield stress $\tau_{0}$ is greater than the shear stress $\tau$, which appears in the fresh concrete.

\begin{tabular}{c|c|c|c|c|c|c|c|}
\hline \multirow{2}{*}{$\begin{array}{c}\text { The mark } \\
\text { of concrete }\end{array}$} & \multicolumn{2}{|c|}{$\tau, \mathrm{Pa}$} & \multicolumn{2}{|c|}{ Checking if condition $\tau_{0} \geq \tau$} \\
\hline $\begin{array}{c}\text { mixture } \\
\text { proportion }\end{array}$ & $\tau_{0}, \mathrm{~Pa}$ & \multicolumn{2}{|c|}{ Angle of inclination, } & \multicolumn{2}{|c|}{ Angle of inclination, } \\
\hline
\end{tabular}

For roughening of plywood surface was used membrane

\begin{tabular}{l|l|l|l|l|l|l|l}
\hline BT1-3 & 416.09 & 281.10 & 526.51 & 760.95 & Stable & Not stable & Not stable \\
\hline BT1-5 & 207.85 & 212.76 & 639.16 & 977.06 & Not stable & Not stable & Not stable \\
\hline
\end{tabular}

For roughening of plywood surface was used geotextile

\begin{tabular}{l|l|l|l|l|l|l|l}
\hline BT1-3 & 416.09 & 251.51 & 765.83 & 1008.25 & Stable & Not stable & Not stable \\
\hline BT1-5 & 207.85 & 212.76 & 245.83 & 586.24 & Not stable & Not stable & Not stable \\
\hline
\end{tabular}

\section{Fig. 6}

View of the inclined plane test method, when for roughening of plywood surface was used membrane

\section{Fig. 7}

View of the inclined plane test method, when for roughening of plywood surface was used geotextile

\section{Table 8}

Comparison of the yield stress and shear stress of fresh concrete, when for roughening of plywood surface were used membrane and geotextile 
Roughening of plywood surface by using membrane and geotextile has an effect on stability of fresh concrete samples, when angle of plane inclination isn't bigger than $25^{\circ}$.

\section{Conclusions}

The test results showed that the increase of coarse aggregate (gravel of fraction 4/16 mm) content from about 417 to $1175 \mathrm{~kg}$ in concrete mixture is enough to achieve the stability of fresh concrete sample, when plane inclination angles are $25^{\circ}, 35^{\circ}$ and $45^{\circ}$, but not enough to stop sliding process. In this case, additional implements are needed to increase the adhesion of fresh concrete to the base. Roughening of plywood surface by using special dimpled membrane and geotextile affects the sliding speed of fresh concrete samples, i.e. its stop sliding process of fresh concrete samples. Due to used membrane studs, which are approx. $8 \mathrm{~mm}$ height, effect on sliding process is bigger compering to geotextile effect on sliding process. Performing concrete work of slope-type structures, roughening of used formwork plywood surface by using special dimpled membrane or geotextile could be new decision to stop sliding process of fresh concrete.

\section{References}

Aissoun B.M., Hwang S., Khayat K.H. Influence of aggregate characteristics on workability of superworkable concrete, Materials and Structures, 2016; 49: 597-609. https://doi.org/10.1617/s11527-0150522-9

Assaad J., Khayat K.H. Influence of internal friction and cohesion on the variations of formwork pressure of self-consolidating concrete, Specal Publication, 222, 2004; 19-32.

$\mathrm{Ba} \mathrm{H}$., Zhang W. Influence of aggregate on the rheological parameters of high-performance concrete, Concrete, 2003; 6: 7-8.

Banfill P.F.G. Rheology of fresh cement and concrete, Rheology Reviews 2006, 2006: 61-130.

Chen J.J., Kwan A.K.H. Superfine cement for improving packing density, rheology and strength of cement paste, Cement and Concrete Composites, 2012; 34: 1-10. https://doi.org/10.1016/j.cemconcomp.2011.09.006

Coussot P., Boyer, S. Determination of yield stress fluid behaviour from inclined pane test, Rheologica Acta, 1995; 34: 534-542. https://doi.org/10.1007/ BF00712314

Dils J., Boel V., De Schutter G., Influence of cement type and mixing pressure on air content, rheology and mechanical properties of UHPC, Construction and Building Materials, 2013; 41: 455-463. https:// doi.org/10.1016/j.conbuildmat.2012.12.050

Harini M., Shaalini G., Dhinakaran G. Effect of size and type of fine aggregates on flowability of mortar, KSCE Journal of Civil Engineering, 2012; 16:163-168. https://doi.org/10.1007/s12205-012-1283-4

Hu J., Wang K. Effect of coarse aggregate characteristics on concrete rheology, Construction and
Building Materials, 2011 ; 25:1196-1204. https://doi. org/10.1016/j.conbuildmat.2010.09.035

Jiao D., Shi C., Yuan Q., An X., Liu Y., Li H. Effect of constituents on rheological properties of fresh concrete-A review, Cement and Concrete Composites, 2017; 83: 146-159. https://doi.org/10.1016/j.cemconcomp.2017.07.016

Kamal H. K., Ahmed F. O., Trimbak V. P. Inclined plane test to evaluate structural buildup at rest of self-consolidating concrete, $\mathrm{ACl}$ Materials Journal, 2010; 1-9.

Khayat K.H., Omran A.F. Evaluation of SCC formwork pressure, Feature, 2009; 16-21.

Khayat K.H., Omran A.F., Pavate T.V., Inclined plane test to evaluate structural buildup at rest of self-consolidating concrete. ACI Materials Journal, 2010; 107: 515-522. https://doi.org/10.14359/51663972

Koehler E.P., Fowler D.W. Development of a portable rheometer for fresh portland cement concrete, ICAR Report 105-3F, 2004; 103-105.

Mork J.H., Gjorv O.E. Effect of gypsum-hemihydrate ratio in cement on rheological properties of fresh concrete, ACl Material Journal, 1997; 94: 142-146. https://doi.org/10.14359/295

Santos A.C.P., Ortiz-Lozano J.A., Villegas N., et al. Experimental study about the effects of granular skeleton distribution on the mechanical properties of self-compacting concrete (SCC), Construction and Building Materials, 2015; 78: 40-49. https://doi. org/10.1016/j.conbuildmat.2015.01.006

Skripkiūnas G. Optimization of concrete macrostructure according to technological and performance properties and raw material resources, Ph.D.-thesis, Kaunas university of technology, 1993 (Lithuanian). 
Wallevik J.E. Rheology of particle suspensions fresh concrete, mortar and cement paste with various types of lignosulfonates. Ph.D.-thesis, Norwegian university of science and technology, 2003.

Westerholm M., Lagerblad B., Silfwerbrand J., et al. Influence of fine aggregate characteristics on the rheological properties of mortars, Cement and Concrete Composites, 2008; 30: 274-282. https://doi. org/10.1016/j.cemconcomp.2007.08.008
Zhang J., Xuehui A., Ding N. Effect of fine aggregate characteristics on the thresholds of self-compacting paste rheological properties. Construction and Building Materials, 2016; 116: 355-365. https://doi. org/10.1016/j.conbuildmat.2016.04.069

Žiogas V. A., Juočiūnas S., Medelienè V., Žiogas G. Concreting and early hardening processes in monolithic reinforced concrete structures, Engineering structures and technologies, 2012; 4: 67-75. https:// doi.org/10.3846/2029882X.2012.699258

\section{ROKAS KUDIRKA}

Master

at Faculty of Civil Engineering and Architecture

\section{Main research area}

Civil engineering.

\section{Address}

Studentu str. 48, LT-51367

Kaunas, Lithuania

Tel. +370 37300473

E-mail:1rokas@inbox.lt

\section{MINDAUGAS DAUKŠYS}

Dr.

Faculty of Civil Engineering and Architecture

\section{Main research area}

Civil engineering, construction technology.

Address

Studentu str. 48, LT-51367

Kaunas, Lithuania

Tel. +370 37300473

E-mail: mindaugas.dauksys@ktu.lt

\section{SVAJŪNAS JUOČIŪNAS}

Lecturer

Faculty of Civil Engineering and Architecture

\section{Main research area}

Civil engineering, construction technology.

Address

Studentu str. 48, LT-51367

Kaunas, Lithuania

Tel. +370 37300473

E-mail: svajunas.juociunas@ktu.lt

\section{About the} Authors 